Jurnal Akuntansi dan Investasi, Vol. 18 No. 1, Hlm: 28-47, Januari 2017

Artikel ini tersedia di website: http://journal.umy.ac.id/index.php/ai

DOI: $10.18196 /$ jai.18159

\title{
Determinan Transparansi dan Akuntabilitas Pengelolaan Keuangan Daerah dan Implikasinya terhadap Kepercayaan Public-Stakeholders
}

Baiq Nurrizkiana; Lilik Handayani; Erna Widiastuty

Program Magister Akuntansi Universitas Mataram, Jl. Pemuda No. 35 Mataram, NTB, Indonesia

\begin{tabular}{l}
\hline A R T I C L E I N F O \\
\hline Article history: \\
received 17 Nov 2015 \\
revised 28 Jun 2016 \\
accepted 4 Sep 2016
\end{tabular}

Keywords:

Financial Statements

Presentation; Financial

Statements Accessibility;

Transparency;

Accountability;

Trust of Public-

Stakeholders

\begin{abstract}
A B S T R A C T
This research aimed to examine the influence of the financial statements presentation and accessibility toward transparency and accountability of regional financial management, followed by examine the influence of transparency and accountability of regional financial management toward the trust of Publicstakeholders. This research is explanatory research. Sampling in this research using purposive sampling method, then determined a sample of 233 respondents from internal public-stakeholders as many as 83 people, namely 30 heads and 30 chief financial officer of SKPD/agencies, and 23 auditors of East Lombok district government inspectorate, with consideration that they are understand and responsible for the presentation and availability of financial statements. Samples are derived from external public-stakeholders as many as 50 members of Parliament in East Lombok, 35 NGO activists / Management Foundation, 35 journalists who are users of financial information and 30 businessmen taxpayer / levy. Analysys methods used in testing the hypothesis is the Partial Least Square Analysis. The results showed that the financial statements presentation and accessibility partially positive and significant influence toward the transparency and accountability of regional financial management. Similarly with the transparency and accountability of regional financial management partially positive and significant influence toward the trust of public-stakeholders.
\end{abstract}

(C) 2017 JAI. All rights reserved

\section{PENDAHULUAN}

Undang-undang No. 28 Tahun 1999 tentang Penyelenggaraan Negara yang Bersih dan Bebas dari Korupsi, Kolusi, dan Nepotisme menyatakan bahwa transparansi dan akuntabilitas merupakan dua dari beberapa asas yang harus dipenuhi oleh pemerintah termasuk pemerintah daerah. Transparansi dan akuntabilitas tidak hanya menjadi kewajiban pemerintah pusat tetapi juga pemerintah daerah sesuai dengan amanat Undang-undang No. 32 Tahun 2004 mengenai pemerintah daerah (pemda). Pemda melaksanakan transparansi dan akuntabilitas karena kewajiban dan adanya tekanan yang kuat dari pemerintah pusat. Dipertegas oleh Peraturan Menteri Dalam Negeri Nomor 59 Tahun 2007 tentang Perubahan atas Peraturan Menteri Dalam Negeri Nomor 13 Tahun 2006 tentang Pedoman Pengelolaan Keuangan Daerah, dijelaskan untuk memenuhi asas tansparansi, kepala daerah wajib menginformasikan substansi Anggaran Pendapatan dan Belanja Daerah (APBD) kepada masyarakat yang telah diundangkan dalam Lembaran Daerah.

Penjelasan Undang-Undang No. 17 Tahun 2003 tentang Keuangan Negara dinyatakan bahwa Kepala Daerah merupakan pengelola keuangan daerah. Ini juga dijelaskan dalam Peraturan Pemerintah Republik Indonesia No. 58 Tahun 2005 tentang Pengelolaan Keuangan Daerah pasal 1 ayat (10) yang menyatakan bahwa Pemegang Kekuasaan Pengelolaan Keuangan Daerah adalah kepala daerah yang karena jabatannya mempunyai kewenangan menyelenggarakan keseluruhan pengelolaan keuangan daerah. Dalam mengelola keuangan daerah, kepala daerah melimpahkan sebagian atau seluruh kekuasaannya dengan berpedoman pada peraturan perundangan-undangan. Selanjutnya, dalam Peraturan Daerah Kabupaten Lombok Timur Nomor 7 Tahun 2009 tentang 
Pokok-Pokok Pengelolaan Keuangan Daerah di Kabupaten Lombok Timur, pasal 5 ayat (3) menyatakan bahwa Pemegang Kekuasaan Pengelolaan Keuangan Daerah melimpahkan sebagian atau seluruh kekuasaannya kepada sekretaris daerah selaku koordinator Pengelolaan Keuangan Daerah, kepala satuan kerja Pengelola Keuangan Daerah (SKPKD) selaku Pejabat Pengelola Keuangan Daerah (PPKD) dan kepala SKPD selaku Pejabat Pengguna Anggaran/Barang Daerah. Selanjutnya, pasal 8 menjelaskan bahwa PPKD selaku Bendahara Umum Daerah (BUD) menunjuk pejabat di lingkungan Satuan Kerja Pengelola Keuangan Daerah selaku Kuasa BUD yang bertanggungjawab kepada PPKD dan ditetapkan berdasarkan keputusan Bupati.

Komposisi dan alokasi belanja pemerintah daerah akan berdampak terhadap pertumbuhan ekonomi dan kesejahteraan masyarakat. Sejalan dengan penelitian Sularso dan Restianto (2011), alokasi belanja modal memberikan pengaruh positif terhadap pertumbuhan ekonomi. Penelitian Yustie dan Heriqbaldi (2014) menyimpulkan bahwa belanja modal berpengaruh signifikan terhadap tingkat kemiskinan kabupaten/kota di Provinsi Jawa Timur. Dengan demikian, kinerja APBD atau pengelolaan keuangan daerah yang baik dapat meningkatkan kesejahteraan dan kepercayaan masyarakat (Murtin, 2008).

Menurut Grosso dan Gregg (2011) untuk mencapai kepuasan masyarakat, maka salah satu cara yang dapat dilakukan oleh pemerintah adalah menerbitkan laporan keuangan dan laporan kinerja pemerintah untuk menjaga akuntabilitas dan transparansi. Apabila pemerintah tidak akuntabel dan transparan, maka akan menimbulkan dampak negatif kepada masyarakat, seperti kurangnya kepercayaan masyarakat kepada pemerintah (Judith et al., 2009) serta timbulnya korupsi dan penyalahgunaan wewenang (Ridha dan Basuki, 2012). Menurut Jones et al. (1985) dan Steccolini (2002) ketidakmampuan laporan keuangan dalam melaksanakan akuntabilitas, tidak saja disebabkan karena laporan keuangan yang tidak memuat semua informasi relevan yang dibutuhkan para pengguna, tetapi juga karena laporan tersebut tidak dapat secara langsung tersedia dan aksesibel kepada para pengguna potensial. Salah satu prasyarat untuk dapat meningkatkan transparansi dan akuntabilitas pengelolaan keuangan negara (pusat dan daerah) adalah dengan melakukan reformasi dalam penyajian laporan keuangan. Pemerintah harus mampu menyediakan semua informasi keuangan relevan secara jujur dan terbuka kepada publik, karena kegiatan pemerintah adalah dalam rangka melaksanakan amanat rakyat (Mulyana, 2006; Pratolo, 2008).

Laporan keuangan sektor publik merupakan representasi terstruktur posisi keuangan akibat transaksi yang dilakukan. Sebagai organisasi yang mengelola dana masyarakat, Pemerintah Kabupaten Lombok Timur harus mampu memberikan pertanggungjawaban publik melalui laporan keuangannya. Penyajian informasi yang utuh dalam laporan keuangan akan menciptakan transparansi dan nantinya akan mewujudkan akuntabilitas (Nordiawan, 2010). Semakin baik penyajian laporan keuangan pemerintah daerah maka akan berimplikasi terhadap peningkatan terwujudnya akuntabilitas pengelolaan keuangan daerah. Aksesibilitas laporan keuangan merupakan kemudahan bagi seseorang untuk memperoleh informasi mengenai laporan keuangan. Akuntabilitas yang efektif tergantung kepada akses publik terhadap laporan keuangan yang dapat dibaca dan dipahami (Mulyana, 2006). Masyarakat sebagai pihak yang memberi kepercayaan kepada pemerintah untuk mengelola keuangan publik berhak untuk mendapatkan informasi keuangan pemerintah untuk melakukan evaluasi terhadap pemerintah (Mardiasmo, 2002).

Mulyana (2006), Bandariy (2011), Aliyah dan Nahar (2012), dan Wahyuni (2014) telah melakukan penelitian untuk menguji secara empiris pengaruh penyajian laporan keuangan dan aksesibilitas laporan keuangan terhadap transparansi dan akuntabilitas pengelolaan keuangan daerah. Hasil penelitian mereka menunjukkan bahwa penyajian laporan keuangan daerah dan aksesibilitas laporan keuangan daerah berpengaruh positif dan signifikan terhadap transparansi dan akuntabilitas pengelolaan keuangan daerah. Sukhemi (2010) melakukan penelitian untuk memberikan bukti empiris tentang pengaruh penyajian neraca daerah terhadap akuntabilitas keuangan daerah dan hasil penelitiannya menunjukkan bahwa penyajian neraca daerah berpengaruh secara positif dan signifikan terhadap akuntabilitas keuangan daerah.

Selanjutnya, Mustafa (2012) dan Sande (2013) menguji secara empiris pengaruh penyajian laporan keuangan daerah dan aksesibilitas laporan keuangan terhadap akuntabilitas pengelolaan keuangan daerah oleh para pengguna Laporan keuangan. Hasil penelitian mereka menunjukkan bahwa penyajian laporan keuangan daerah dan aksesibilitas laporan keuangan daerah berpengaruh positif dan signifikan terhadap akuntabilitas penge- 
lolaan keuangan daerah. Hasil penelitian tersebut berbeda dengan hasil penelitian yang dilakukan oleh Safitri (2009) yang menemukan bahwa penyajian laporan keuangan daerah tidak berpengaruh terhadap penggunaan informasi keuangan daerah, dan aksesibilitas laporan keuangan daerah berpengaruh dan signifikan terhadap penggunaan informasi keuangan daerah.

Berbeda juga dengan penelitian yang dilakukan Pasaribu (2011) yang bertujuan untuk mengetahui pengaruh penyajian laporan keuangan SKPD dan aksesibilitas laporan keuangan SKPD terhadap transparansi dan akuntabilitas pengelolaan keuangan SKPD. Hasil penelitiannya menunjukkan bahwa penyajian laporan keuangan SKPD dan aksesibilitas laporan keuangan berpengaruh terhadap transparansi dan akuntabilitas pengelolaan keuangan SKPD, penyajian laporan keuangan SKPD berpengaruh negatif terhadap transparansi dan akuntabilitas laporan keuangan SKPD, dan aksesibilitas laporan keuangan SKPD berpengaruh terhadap transparansi dan akuntabilitas laporan keuangan SKPD.

Riyansa et al. (2015) menguji secara empiris pengaruh penyajian laporan keuangan dan aksesibilitas laporan keuangan terhadap akuntabilitas pengelolaan keuangan daerah di Kabupaten Padang Pariaman. Hasil penelitiannya menunjukkan penyajian laporan keuangan tidak berpengaruh signifikan terhadap akuntabilitas pengelolaan keuangan daerah dan aksesibilitas laporan keuangan berpengaruh signifikan terhadap akuntabilitas pengelolaan keuangan daerah.

Studi tentang transparansi dan akuntabilitas terhadap kepercayaan masyarakat pada pemerintah salah satunya dilakukan oleh Rahmawati (2013) yang meneliti pengaruh transparansi dan akuntabilitas pemerintah daerah terhadap kepuasan dan kepercayaan masyarakat di Daerah Istimewa Yogyakarta yang terbagi dalam lima kabupaten/ kota. Hasil penelitian menunjukkan bahwa ada pengaruh akuntabilitas dan transparansi pemerintah daerah terhadap kepuasan dan kepercayaan masyarakat kepada pemerintah daerah. Fard dan Rostamy (2007) juga meneliti pengaruh akuntabilitas terhadap kepuasan dan kepercayaan masyarakat. Hasil penelitian mengindikasikan bahwa akuntabilitas pemerintah mempengaruhi kepercayaan masyarakat kepada pemerintah dengan peningkatan kepuasaan masyarakat atas kinerja pemerintah.

Penelitian yang berhubungan dengan transparansi pemerintah telah dilakukan diantaranya oleh Tolbert dan Mossberger (2006) dan oleh
Welc et al. (2004). Tolbert dan Mossberger (2006) menguji perilaku masyarakat terhadap pelaksanaan e-government dan pengaruhnya terhadap kepercayaan masyarakat kepada pemerintah. Hasil penelitian tersebut menunjukkan bahwa pelaksanaan e-government meningkatkan persepsi masyarakat terhadap transparansi pemerintah. Sementara, hasil penelitian Welch et al. (2004) menemukan bahwa penggunaan e-government dan website pada masyarakat berhubungan positif dengan kepuasan masyarakat kepada pemerintah.

Keberadaan website pemerintah Kabupaten Lombok timur yakni http://lomboktimurkab.go.id/ merupakan salah satu upaya dalam meningkatkan transparansi dan akuntabilitas pemerintahan di Kabupaten Lombok Timur. Melalui website tersebut masyarakat dapat mengakses berbagai aktivitas pemerintah dan perkembangan kegiatan pelaksanaan APBD (e-monev), layanan sistem pengadaan barang yang dilakukan secara elektronik (e-procurement) melalui link LPSE serta data-data penting lainnya yang sangat dibutuhkan oleh para pemangku kepentingan (public-stakeholders) yakni: pejabat birokrasi, wakil rakyat/ DPRD, pengusaha, LSM, akademisi, wartawan dan masyarakat lainnya. Walaupun begitu masih banyak data-data penting yang belum bisa diakses (belum tersedia) dalam sub menu "Transparansi Info" pada menu "Pemerintahan" yakni data-data yang terkait dengan pengelolaan keuangan daerah Kabupaten Lombok Timur seperti laporan neraca dan realisasi anggaran, DPA SKPD, laporan APBD, laporan rencana umum pengadaan, dan laporan penerimaan ZIS, serta link LPSE (eprocurement) yang masih belum bisa diakses sampai saat ini'.

Terkait dengan transparansi dan akuntabilitas pengelolaan keuangan daerah di Kabupaten Lombok Timur tahun anggaran 2014, BPK RI (Badan Pemeriksa Keuangan Republik Indonesia) menemukan 15 kasus masing-masing 6 (enam) kasus ketidakpatuhan dan kecurangan dalam pengujian kepatuhan terhadap peraturan perundangundangan dan 9 (Sembilan) kasus kelemahan dalam sistem pengendalian intern pada Pemerintah Daerah Kabupaten Lombok Timur. Berdasarkan laporan hasil pemeriksaan BPK RI atas LKPD periode Tahun Anggaran 2014, pemerintah daerah Kabupaten Lombok Timur masih mendapatkan predikat Wajar Dengan Pengecualian (WDP) yang disebabkan oleh permasalahan aset yang belum

1 diakses jum'at, 22 Januari 2016 
diselesaikan secara menyeluruh dan tata kelola laporan keuangan yang kurang baik. Bahkan menurut BPK RI, pemerintah daerah Kabupaten Lombok Timur memiliki tingkat pelanggaran atau nilai temuan diatas angka Planing Materiality.

Laporan hasil pemeriksaan BPK RI tersebut menunjukkan bahwa kondisi Kabupaten Lombok Timur belum berhasil melaksanakan salah satu misi yang telah ditetapkan oleh Pemerintah Daerah Kabupaten Lombok Timur periode 20132018 yang menyatakan yakni "meningkatkan tata kelola pemerintahan yang baik". Terkait dengan misi tersebut, pemerintah menetapkan tujuan yang ingin dicapai dalam kurun waktu 5 (lima) tahun, yaitu "Mewujudkan pengelolaan pemerintahan yang efektif dan efisien", yang sasarannya adalah meningkatnya profesionalisme dan kesejahteraan aparatur, penataan kelembagaan perangkat daerah, meningkatnya penguatan kapasitas pemerintahan desa, meningkatnya akuntabilitas kinerja pemerintah daerah, meningkatnya akuntabilitas kinerja pengelolaan keuangan daerah, ketersediaan dokumen perencanaan di semua SKPD, meningkatnya kemitraan eksekutif dan legislatif, serta mencegah praktek KKN.

Penelitian-penelitian terdahulu yang telah diuraikan di atas menunjukkan adanya perbedaan hasil penelitian (gap research) tentang pengaruh penyajian dan aksesibilitas laporan keuangan terhadap akuntabilitas dan transparansi pengelolaan keuangan daerah. Hal ini menjadi salah satu alasan peneliti untuk menguji dan menganalisa kembali pengaruh penyajian dan aksesibilitas laporan keuangan sebagai faktor penentu akuntabilitas dan transparansi pengelolaan keuangan daerah di Kabupaten Lombok Timur. Penelitian ini mengeksplorasikan pengaruh penyajian dan aksesibilitas laporan keuangan daerah terhadap transparansi dan akuntabilitas pengelolaan keuangan daerah serta mengelaborasi pengaruh transparansi dan akuntabilitas pengelolaan keuangan daerah terhadap kepercayaan public-stakeholders.

Rahmawati (2013), Fard dan Rostamy (2007), Tolbert dan Mossberger (2006), dan Welch et al. (2004) telah melakukan penelitian tentang pengaruh transparansi dan akuntabilitas pemerintah terhadap kepuasan dan kepercayaan masyarakat pada tempat dan waktu yang berbeda tetapi menemukan hasil yang sama dimana transparansi dan akuntabilitas pemerintah berpengaruh positip dan signifikan terhadap kepuasan dan kepercayaan masyarakat. Penelitian-peneltian tersebut membahas mengenai transparansi dan akuntabilitas pelayanan publik yang dilakukan oleh pemerintah.
Perbedaannya dengan penelitian ini adalah penelitian ini lebih menekankan untuk menguji pengaruh transparansi dan akuntabilitas pengelolaan keuangan daerah oleh pemerintah terhadap kepercayaan public-stakeholder. Penelitian ini juga mengembangkan pengujian menggunakan analisis Partial Least Square (smartPLS).

Dari penelitian ini, diharapkan dapat memberikan kontribusi praktis berupa informasi yang berguna dalam perumusan arah dan kebijakan terkait akuntabilitas dan transparansi pelaporan keuangan pemda. Dalam hal teoritis, penelitian ini menjadi literatur tambahan dalam pengembangan konsep good government governance, khususnya terkait aspek akuntabilitas dan transparansi di lembaga pemerintahan.

\section{TINJAUAN LITERATUR DAN PERUMUSAN HIPOTESIS}

\section{Pengaruh Penyajian Laporan Keuangan Daerah terhadap Transparansi Pengelolaan Keuangan Daerah}

Teori keagenan menjelaskan mengenai dua pihak yang melakukan kesepakatan atau kontrak yang memiliki permasalahan berupa asimetri informasi. Pada sektor publik, (pemda) sebagai pihak yang menyelenggarakan pelayanan publik memiliki informasi lebih banyak sehingga dapat membuat keputusan atau kebijakan yang hanya mementingkan pemerintah dan penguasa serta mengabaikan kepentingan dan kesejahteraan rakyat. Bupati dan Wakil Bupati selaku agen yang diamanahi prinsipal (rakyat) harus mampu mempertanggungjawabkan dan mempertanggungjelaskan kinerjanya. Di dalam mengelola amanah, Bupati dan Wakil Bupati adalah pihak yang terinformasi dari pada prinsipal. Untuk tujuan mekanisme kontrol tentang apa yang telah dilakukan oleh manajer (Sekertaris Daerah, Kepala SKPD, Kepala SKPKD dan Kepala Badan-Badan), maka laporan keuangan daerah yang disusun merupakan mekanisme tanggung jawab dan tanggung jelas terhadap kinerjanya kepada Bupati sebagai penguasa pengelola keuangan daerah, yang selanjutnya disampaikan sebagai pertanggungjawaban Bupati kepada rakyat (pemilik).

Penyajian informasi yang utuh dalam laporan keuangan akan menciptakan transparansi dan nantinya menciptakan akuntabilitas (Nordiawan, 2010). Dengan demikian, maka semakin baik 
penyajian laporan keuangan daerah maka semakin transparan pengelolalaan keuangan daerah. Berdasarkan uraian di atas, maka dapat dirumuskan hipotesis sebagai berikut:

H1a: Penyajian laporan keuangan daerah berpengaruh positif dan signifikan terhadap transparansi pengelolaan keuangan daerah.

\section{Pengaruh Penyajian Laporan Keuangan Daerah terhadap Akuntabilitas Pengelolaan Keuangan Daerah}

Teori keagenan menyatakan bahwa agen dan prinsipal memiliki kepentingan yang berbeda (Eisenhardt, 1989). Prinsipal tentu menginginkan hasil kinerja yang baik dari agen dan agen berkewajiban mempertanggungjawabkan kinerjanya kepada masyarakat (prinsipal) melalui laporan keuangan yang berkualitas (Puspita dan Martani, 2010). Nordiawan (2010) menegaskan penyajian informasi yang utuh dalam laporan keuangan akan menciptakan transparansi dan nantinya akan menciptakan akuntabilitas. Semakin baik pemerintah daerah dalam menyajikan laporan keuangan, maka semakin meningkat akuntabilitas pengelolaan keuangan daerah (Mudhofar dan Tahar, 2016). Berdasarkan uraian di atas, maka dapat dirumuskan hipotesis sebagai berikut:

H1b: Penyajian laporan keuangan daerah berpengaruh positif dan signifikan terhadap akuntabilitas pengelolaan keuangan daerah.

Pengaruh Aksesibilitas Laporan Keuangan Daerah Terhadap Transparansi Pengelolaan Keuangan Daerah

Dalam teori keagenan, tanggung jawab yang ditunjukkan pemerintah daerah sebagai agen tidak hanya berupa penyajian laporan keuangan yang lengkap dan wajar, tetapi juga pada bagaimana mereka mampu membuka akses dan mengungkapkan laporan keuangan untuk para pemangku kepentingan yang berkepentingan dengan laporan keuangan. Pemerintah daerah sebagai agen akan menghindari risiko berupa ketidakpercayaan public-stakeholders terhadap kinerja mereka (Safitri, 2009).

Aksesibilitas laporan keuangan merupakan kemudahan bagi seseorang untuk memperoleh informasi mengenai laporan keuangan. Penggunaan informasi keuangan yang efektif tergantung kepada akses publik terhadap laporan keuangan yang dapat dibaca dan dipahami (Nordiawan 2010). Masyarakat sebagai pihak yang memberi kepercayaan kepada pemerintah untuk mengelola keuangan publik berhak untuk mendapatkan informasi keuangan pemerintah untuk melakukan evaluasi terhadap pemerintah (Mardiasmo, 2002). Semakin mudah masyarakat mengakses laporan keuangan daerah, maka semakin transparan dan akuntabel pengelolaan keuangan daerah oleh agen yang telah dipilih oleh rakyat (prinsipal). Situasi ini hendaknya bisa dimanfaatkan oleh pemerintah daerah untuk membuka segala informasi yang dibutuhkan oleh prinsipal maupun public-stakeholders lainnya. Berdasarkan uraian di atas, maka dapat dirumuskan hipotesis sebagai berikut:

H2a: Aksesibilitas laporan keuangan berpengaruh positif dan signifikan terhadap transparansi pengelolaan keuangan daerah.

\section{Pengaruh Aksesibilitas Laporan Keuangan Daerah terhadap Akuntabilitas Pengelolaan Keuangan Daerah}

Dalam teori agensi, informasi akuntansi manajemen digunakan untuk dua tujuan, yakni: pertama, digunakan untuk pengambilan keputusan oleh prinsipal dan agen; kedua, digunakan untuk mengevaluasi dan membagi hasil sesuai dengan kontrak kerja yang telah dibuat dan disetujui (Raharjo, 2007). Kemudahan dalam mengakses laporan keuangan pemerintah sebagai agen sangat penting bagi prinsipal sebagai bentuk pertanggungjawaban atas kontrak atau program-program pemerintah yang dibahas dalam musrenbang pemerintah ataupun janji-janji yang pernah disampaikan oleh pemerintah (agen) dalam kampanyenya. Akuntabilitas yang efektif dipengaruhi oleh akses publik terhadap laporan pertanggungjawaban maupun laporan hasil pemeriksaan. Akses publik difasilitasi melalui media, seperti surat kabar, majalah, radio, stasiun televisi, dan internet, serta forum yang memberikan perhatian langsung atau peranan yang mendorong akuntabilitas pemerintah terhadap masyarakat (Shende dan Bennet, 2004). Berdasarkan uraian di atas, maka dirumuskan hipotesis sebagai berikut:

H2b: Aksesibilitas laporan keuangan berpengaruh positif dan signifikan terhadap akuntabilitas pengelolaan keuangan daerah.

\section{Transparansi Pengelolaan Keuangan Daerah dan Kepercayaan Public-Stakeholder}

Salah satu prinsip kepemerintahan yang baik menurut Peraturan Pemerintah No. 101 tahun 2000 adalah transparansi menciptakan keper- 
cayaan timbal-balik antara pemerintah dan masyarakat melalui penyediaan informasi dan menjamin kemudahan di dalam memperoleh informasi yang akurat dan memadai. Seluruh public-stakeholders memiliki kesempatan memperoleh akses informasi yang terkait dengan pemerintahan daerah. Bila agen dan prinsipal memiliki informasi yang seimbang, maka akan mengurangi perilaku oportunis pihak agen dan dapat meminimalisir anggapan bahwa agen tidak dapat dipercaya. Semakin terbuka pengelolaan keuangan daerah maka semakin meningkatkan kepercayaan public-stakeholders terhadap pemda.

Teori Pensinyalan (Signalling Theory) dalam ranah publik diwujudkan dalam bentuk penyusunan laporan keuangan yang berkualitas, peningkatan sistem pengendalian intern, dan pengungkapan yang lebih lengkap. Sinyal tersebut merupakan bentuk keterbukaan/transparansi yang berimplikasi terhadap meningkatnya kepercayaan masyarakat kepada pemerintah (Puspita dan Martani, 2010). Sementara, dalam konsep Stewardship Theory mengasumsikan bahwa agen bekerja didasari pada asas kepercayaan pada pihak yangmemiberikan wewenang, dimana manajemen dalam suatu organisasi dicerminkan sebagai good steward yang melaksanakan tugas yang diberikan oleh atasannya secara penuh tanggungjawab (Sakinatantri, 2002). Dalam penelitian ini, pemda bertindak sebagai good stewards yang mengarahkan semua kemampuan dan keahliannya dalam menyajikan dan menyediakan informasi yang bermanfaat bagi organisasi dan para pengguna informasi keuangan pemerintah, baik secara langsung atau tidak langsung melalui wakil rakyat/legislatif dalam rangka mewujudkan transparansi dan akuntabilitas pengelolaan keuangan daerah.

Menurut Tschannen-Moran dan Hoy (2001), salah satu aspek kepercayaan itu adalah keterbukaan (openess), sehingga semakin transparan/ terbuka pengelolaan keuangan pemda, maka kepercayaan masyarakat semakin meningkat kepada pemerintah daerah sebagai good steward. Berdasarkan uraian di atas, maka dapat dirumuskan hipotesis sebagai berikut:

H3: Transparansi pengelolaan keuangan daerah berpengaruh positif dan signifikan terhadap kepercayaan public-stakeholders.

\section{Akuntabilitas Pengelolaan Keuangan Daerah dan Kepercayaan Public-Stakeholder}

Akuntabilitas publik dalam konteks organisasi pemerintah adalah pemberian informasi dan peng- ungkapan atas aktivitas dan kinerja finansial pemerintah kepada pihak-pihak yang berkepentingan dengan laporan tersebut (Mardiasmo, 2002). Akuntabilitas publik bertujuan untuk mendorong terciptanya kinerja yang baik dan terpercaya. Semakin tinggi tingkat akuntabilitas pengelolaan keuangan daerah maka semakin tinggi kepercayaan public-stakeholders terhadap pemda (Mardiasmo, 2002 ).

Dalam sudut pandang signalling theory, pemda selaku agen akan berupaya mengurangi asimetri informasi keuangan daerah dengan cara menghasilkan informasi laporan keuangan yang berkualitas dan berintegritas. Secara kongkrit, pemerintah daerah melalui auditor inspektorat daerah melakukan reviu terhadap laporan keuangan daerah dan perlu mendapatkan opini baik dari pihak independen, dalam hal ini adalah BPK RI. Sinyal positif dalam bentuk akuntabilitas dan transparansi ini menunjukkan kepada masyarakat bahwa pemda telah melaksanakan kewajiban dan tanggungjawabnya sebagai pengemban amanat rakyat (Puspita dan Martani, 2010). Semakin baik sinyal (akuntabilitas) yang disampaikan, maka akan semakin tinggi tingkat kepercayaan masyarakat (Gunawan, 2000).

Penelitian Rahmawati (2013) menunjukkan bahwa akuntabilitas pemda berpengaruh terhadap kepuasan dan kepercayaan masyarakat kepada pemda. Untuk itu pemda harus menjaga kepercayaan masyarakat dengan meningkatkan akuntabilitas pengelolaan keuangan daerah. Berdasarkan uraian di atas, maka hipotesis yang diajukan adalah sebagai berikut:

H4: Akuntabilitas pengelolaan keuangan daerah berpengaruh positif dan signifikan terhadap kepercayaan public-stakeholders.

\section{METODE PENELITIAN}

\section{Populasi dan Sampel}

Populasi dalam penelitian ini adalah Sekretariat Daerah, Sekretariat Dewan Perwakilan Daerah (DPRD), semua Satuan Kerja Perangkat Daerah (SKPD) dan Badan-Badan pada pemda Kabupaten Lombok Timur, yang selanjutnya disebut public-stakeholders internal. Dewan Perwakilan Rakyat Daerah (DPRD), pengusaha, Lembaga Swadaya Masyarakat (LSM) dan atau Yayasan, dan wartawan di Kabupaten Lombok Timur, selanjutnya disebut sebagai publicstakeholders eksternal (Nugraha, 2007). 
Teknik pengambilan sampel yang digunakan adalah purposive sampling; yaitu teknik penentuan sampel dengan pertimbangan tertentu untuk mendapatkan sampel yang refresentatif (Sugiyono, 2010). Adapun pertimbangan dalam pengambilan sampel adalah sebagai berikut:

(1) Sampel yang diambil berasal dari publicstakeholders internal adalah kepala dinas/ badan, kasubag keuangan dan auditor inspektorat pemerintah daerah kabupaten Lombok Timur dengan pertimbangan bahwa sampel yang dipilih ini pejabat terkait yang memahami dan bertanggungjawab atas penyajian dan ketersediaan laporan keuangan daerah. Jumlah sampel yang diambil 83 orang terdiri dari 30 kepala SKPD/Badan, 30 Kasubag keuangan, dan 23 auditor Inspektorat pemerintah daerah kabupaten Lombok Timur.

(2) Sampel dari public-stakeholders eksternal sejumlah 150 orang yang terdiri dari 50 anggota DPRD Kabupaten Lombok Timur, aktivis LSM dan Yayasan sebanyak 35 orang dan Wartawan sebanyak 35 orang merupakan pengguna informasi keuangan daerah. Pengusaha sejumlah 30 orang adalah pembayar pajak/retribusi yang merupakan salah satu sumber pendapatan daerah,

\section{Definisi Operasional Variabel}

Indikator yang digunakan untuk mengukur masing-masing variabel penelitian disajikan pada Tabel 1.

\section{Analisis Data}

Penelitian ini menggunakan dua teknik analisa data statistik yaitu statistik deskriptif dan statistik inferensial (Sugiyono, 2013).

\section{Statistik Deskriptif}

Menurut Sugiyono (2013) Statistik deskriptif adalah statistik yang digunakan untuk menganalisis data dengan cara mendiskripsikan atau menggambarkan data yang telah terkumpul sebagaimana adanya tanpa bermaksud membuat kesimpulan yang berlaku untuk umum atau generalisasi.

\section{Statistik Inferensial}

Statistik inferensial, (sering juga disebut statistik induktif atau statistic probabilitas), adalah teknik statistik yang digunakan untuk menganalisis data sampel dan hasilnya diberlakukan untuk populasi (Sugiyono, 2013). Dalam penelitian ini analisis data statistik inferensial menggunakan analisis PLS (Partial Least Square) mulai dari pengukuran model (outer modeh), model struktural (inner modeh), dan pengujian hipotesis. Ada beberapa tahapan dalam PLS yaitu :

(1) Konseptualisasi Model; Pemodelan dalam PLS terdiri atas inner model dan outer model (Hartono dan Abdillah, 2009). Outer model (model pengukuran) menggambarkan hubungan indikator dengan variabel latennya, sedangkan inner model (model struktural) menggambarkan hubungan antar variabel laten.

(2) Menentukan metode analisa algorithma; Penelitian ini menggunakan skema algorithma PLS Path/struktural weighting.

(3) Menentukan metode resampling; Penelitian ini mengunakan metode bootstrapping karena metode ini lebih sering digunakan dalam model persamaan struktural dan karena program SmartPLS 3.0 hanya menyediakan metode resampling bootstrapping.

(4) Menentukan diagram jalur; Diagram jalur dalam penelitian disajikan dalam Gambar 1 .

\section{Model Pengukuran (Outer Model)}

Outer model, sering juga disebut (outer relation atau measurement model), mendefinisikan bagaimana setiap blok indikator berhubungan dengan variabel latennya (Ghozali, 2008).

\section{Evaluasi Model Pengukuran (Outer Model)}

\section{Uji Validitas}

Ghozali (2006) mendefinisikan uji validitas sebagai alat untuk mengukur sah atau valid tidaknya suatu kuesioner. Terdapat dua uji validitas yang digunakan dalam penelitian ini yaitu, convergent validity dan discriminant validity. Convergent validity (Validitas Konvergen) dinilai berdasarkan loading factor indikator-indikator yang mengukur konstruk tersebut (Hartono, 2011). Ukuran reflektif individual dikatakan tinggi jika berkorelasi lebih dari 0,70 dengan konstruk yang ingin diukur. Namun, demikian untuk penelitian tahap awal dari pengembangan skala pengukuran nilai loading factor 0,5 sampai 0,6 dianggap cukup (Ghozali, 2008). Discriminant validity (Validitas 
Tabel 1. Indikator dan Pengukuran Variabel

\begin{tabular}{|c|c|c|c|c|}
\hline No & Variabel & Indikator & Pengukuran & $\begin{array}{c}\text { Nomor } \\
\text { Pertanyaan }\end{array}$ \\
\hline 1 & $\begin{array}{l}\text { Penyajian Laporan } \\
\text { Keuangan (PLK) }\end{array}$ & $\begin{array}{l}\text { a. Andal, } \\
\text { b. Relevan, } \\
\text { c. Dapat dibandingkan, } \\
\text { d. Dapat dipahami. } \\
\text { (Diadopsi dari Peraturan Pemerintah Republik } \\
\text { Indonesia Nomor } 71 \text { tahun 2010) }\end{array}$ & Skala Likert & $1-4$ \\
\hline 2 & $\begin{array}{l}\text { Aksesibilitas } \\
\text { Laporan } \\
\text { Keuangan (ALK) }\end{array}$ & $\begin{array}{l}\text { a. Keterbukaan } \\
\text { a. Kemudahan } \\
\text { b. Accesibel } \\
\text { (Diadopsi dari Penelitian Sande, (2013) ) }\end{array}$ & Skala Likert & $5-7$ \\
\hline 3 & $\begin{array}{l}\text { Transparansi } \\
\text { Pengelolaan } \\
\text { Keuangan daerah } \\
\text { (TPKD) }\end{array}$ & $\begin{array}{l}\text { a. Ketersediaan sistem informasi, } \\
\text { b. Aksesibilitas terhadap laporan keuangan daerah, } \\
\text { c. Publikasi laporan keuangan daerah, } \\
\text { d. Ketersediaan Laporan pemeriksaan, } \\
\text { e. Ketersediaan informasi kinerja } \\
\text { (Diadopsi dari Penelitian Ramadhani, (2011) }\end{array}$ & Skala Likert & $8-12$ \\
\hline 4 & $\begin{array}{l}\text { Akuntabilitas } \\
\text { Pengelolaan } \\
\text { Keuangan daerah } \\
\text { (APKD) }\end{array}$ & $\begin{array}{l}\text { a. Pertanggungjawaban dana publik } \\
\text { b. Jenis dan bentuk laporan keuangan hasil } \\
\text { investigasi } \\
\text { c. Penyajian tepat waktu } \\
\text { d. Pemeriksaan (audit) } \\
\text { e. Respon yang cepat } \\
\text { (Diadopsi dari Penelitian Ramadhani, (2011)) }\end{array}$ & Skala Likert & $13-17$ \\
\hline 5 & $\begin{array}{l}\text { Kepercayaan } \\
\text { Stakeholders (KS) }\end{array}$ & $\begin{array}{l}\text { a. Keyakinan dan Kepercayaan publik/public- } \\
\text { stakeholders } \\
\text { b. Partisipasi publik/stakeholders } \\
\text { c. Wawasan dan pengetahuan public-stakeholders } \\
\text { d. Ketaatan terhadap aturan } \\
\text { e. kepercayaan dan kepuasan public-stakeholders } \\
\text { f. Kesadaran public-stakeholders akan haknya } \\
\text { g. Kesesuaian kegiatan-kegiatan pemerintah daerah } \\
\text { h. Berkurangnya kasus-kasus KKN } \\
\text { (Diadopsi dari Penelitian krisnayanti, (2013)) }\end{array}$ & Skala Likert & $18-25$ \\
\hline
\end{tabular}

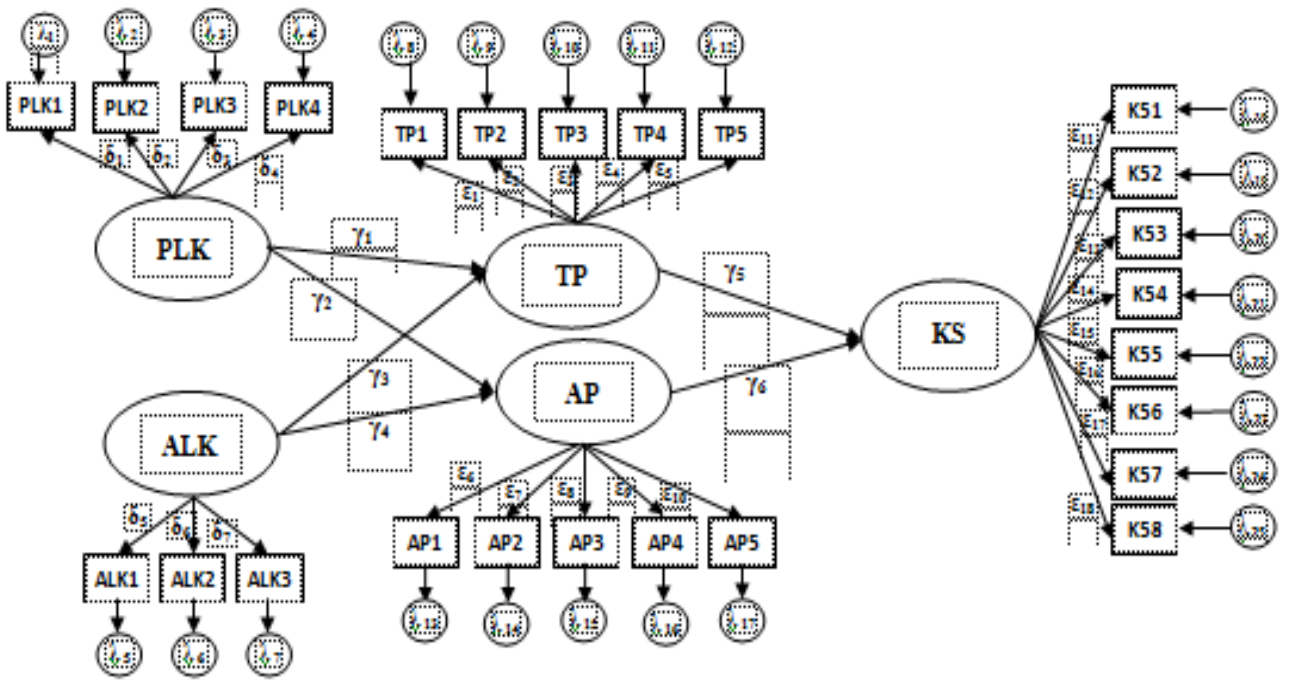

Gambar 1. Ilustrasi Model Struktural 
Diskriminan) berhubungan dengan prinsip bahwa pengukur-pengukur konstruk yang berbeda seharusnya tidak berkorelasi tinggi. Validitas diskriminan terjadi jika dua instrumen yang berbeda mengukur dua konstruk yang diprediksi tidak berkorelasi menghasilkan skor yang memang tidak berkorelasi. Discriminat validity dari model pengukuran dengan reflektif indikator dinilai berdasarkan cross loading pengukuran dengan konstruk. Nilai korelasi cross loading dengan variabel latennya harus lebih besar dibandingkan dengan korelasi terhadap variabel laten yang lain. Metode lain untuk menilai Discriminant validity adalah membandingkan nilai square root of average variance extrated (AVE) setiap konstruk dengan korelasi antara konstruk dengan konstruk lainnya dalam model (Ghozali, 2008; Hartono, 2011). Nilai square root of average variance extracted (AVE) direkomendasikan nilai AVE harus lebih besar 0,50 (lihat juga: Sofyani dan Akbar, 2013; 2015)

\section{Uji Reliabilitas}

Uji reliabilitas adalah alat untuk mengukur suatu kuesioner berdasar indikator dari variabel atau konstruk. Suatu kuesioner dikatakan reliable atau handal jika jawaban seseorang terhadap pertanyaan adalah konsisten dari waktu ke waktu (Ghozali, 2006). Uji reliabilitas dalam PLS dapat menggunakan dua metode, yaitu composite reliability dan Cronbach's Alpha (Hartono, 2011). Rule of thumb nilai alpha atau composite reliability yang baik harus lebih besar dari 0,7 meskipun nilai 0,6 masih dapat diterima (Hair et al., 1995 sebagaimana dikutip Hartono, 2011).

\section{Persamaan model pengukuran (outer model) penelitian}

Persamaan model pengukuran (outer model) dalam penelitian ini disajikan pada Gambar 1 dengan rincian penjelasan sebagai berikut:

(1) Variabel Penyajian Laporan Keuangan (PLK); $\mathrm{PLK}_{1-4}=\lambda_{1-4} \mathrm{PLK}+\delta_{1-4}$

(2) Variabel Aksesibilitas Laporan Keuangan $(\mathrm{ALK}) ; \mathrm{ALK}_{1-3}=\lambda_{i-7} \mathrm{ALK}+\delta_{5-7}$

(3) Variabel Transparansi Pengelolaan Keuangan Daerah (TP); $\mathrm{TP}_{1-5}=\lambda_{8-12} \mathrm{TP}+\varepsilon_{1-5}$

(4) Variabel Akuntabilitas Pengelolaa Keuangan Daerah (AP); $\mathrm{AP}_{1-5}=\lambda_{13-17} \mathrm{AP}+\varepsilon_{6-10}$

(5) Variabel Kepercayaan Stakeholders (KS);

$$
\mathrm{KS}_{1-8}=\lambda_{1-2-25} \mathrm{KS}+\varepsilon_{11-18}
$$

Keterangan:

PLK = Penyajian laporan keuangan daerah

ALK = Aksesibilitas laporan keuangan Daerah

$\mathrm{TP}=$ Transaparansi Pengelolaan Keuangan Daerah

AP $=$ Akuntabilitas Pengelolaan Keuangan Daerah

$\mathrm{KS}=$ Kepercayaan stakeholders

PLK1 = Andal

PLK2 = Relevan

PLK3 = Dapat dibandingkan

PLK4 = Dapat dipahami

ALK $=$ Keterbukaan

ALK2 = Kemudahan

ALK3 = Accessible

$\mathrm{TP1}=$ Ketersediaan sistem informasi

TP2 = Aksesibilitas terhadap laporan keuangan

TP3 = Publikasi laporan keuangan

$\mathrm{TP} 4=$ Ketersediaan hasil pemeriksaan

TP5 $=$ Ketersediaan informasi kinerja

$\mathrm{AP1}=$ Pertanggungjawaban dana publik

AP2 = Jenis dan bentuk laporan keuangan hasil investigasi

AP3 = Penyajian tepat waktu

$\mathrm{AP} 4=$ Pemeriksaan (audit)

AP5 $=$ Respon yang cepat

$\mathrm{KS} 1=$ Keyakinan dan kepercayaan

$\mathrm{KS} 2=$ Partisipasi

KS3 = Wawasan

$\mathrm{KS} 4=$ Ketaatan

KS5 = Kepercayaan dan kepuasan

KS6 = Kesadaran masyarakat akan hak-haknya

KS7 = Kesesuaian program dengan kebutuhan masyarakat

KS8 = Korupsi, kolusi dan nepotisme $\gamma_{1-4}=$ gamma (kecil), koefisien pengruh langsung variabel eksogen terhadap variabel endogen $\gamma_{j-6}=$ gamma (kecil), koefisien pengaruh langsung variabel endogen terhadap variabel endogen

$\lambda_{1-25}=$ koefisien model pengukuran (outer weight)

$\delta_{1-7}=\operatorname{delta}(\mathrm{kecil})$, galat model pengukuran pada variabel laten endogen

$\boldsymbol{\varepsilon}_{1-18}=$ epsilon, galat model pengukuran pada variabel laten endogen

\section{Model Struktural (Inner Model)}

Menurut Ghozali (2008) dan Hartono (2011) model struktural/evaluasi measurement model (inner model) merupakan model struktural untuk memprediksi hubungan kausalitas antar variabel laten. 


\section{Evaluasi Model Struktural (Inner Model)}

\section{Goodness of Fit}

Goodness of fit pada inner model diukur menggunakan $\mathrm{R}$ square variabel laten dependen, $\mathrm{Q}$ square predictive relevance untuk model struktural yang digunakan untuk mengukur seberapa baik nilai observasi dihasilkan oleh model dan juga estimasi parameternya. Nilai Q square lebih dari 0 menunjukkan model memiliki predictive relevance yang baik, dan sebaliknya jika nilai $Q$ square kurang dari atau sama dengan 0 menunjukkan model kurang memiliki predictive relevance.

\section{T-statistic}

Apabila koefisien T-statistik pada tabel Path Coefficient output PLS 3.0 (T-hitung) menunjukan koefisien yang lebih besar $(>)$ dari t-tabel $(1,68)$, maka hasil ini menggambarkan variabel tersebut signifikan dan dapat diartikan bahwa terdapat pengaruh yang bermakna pada variabel laten terhadap variabel laten lainnya.

\section{Persamaan Model Struktural (Inner Model)}

Persamaan model struktural (inner model) dalam penelitian ini berdasarkan Gambar 1:

$\mathrm{TP}=\gamma_{1} \mathrm{PLK}+\gamma_{3} \mathrm{ALK}+\zeta_{1}$

$\mathrm{AP}=\gamma_{2} \mathrm{PLK}+\gamma_{4} \mathrm{ALK}+\zeta_{2}$

$\mathrm{KS}=\gamma_{5} \mathrm{TP}+\gamma_{6} \mathrm{AP}+\zeta_{3}$

Keterangan:

PLK = Penyajian laporan keuangan daerah

ALK $=$ Aksesibilitas laporan keuangan Daerah

$\mathrm{TP}=$ Transaparansi Pengelolaan Keuangan Daerah

AP $=$ Akuntabilitas Pengelolaan Keuangan Daerah

$\mathrm{KS}=$ Kepercayaan stakeholders $\gamma_{1-4}=$ gamma (kecil), koefisien pengruh variabel eksogen terhadap endogen

$\gamma_{5,6}=$ gamma (kecil), koefisien pengaruh variabel endogen terhadap endogen

$\lambda=$ koefisien model pengukuran (outer weight);

$\zeta=$ zeta (kecil), galat model struktural

$\varepsilon=$ epsilon, galat model pengukuran

\section{HASIL DAN PEMBAHASAN}

\section{Distribusi dan Pengembalian Kuesioner}

Jumlah kuesioner yang disebar kepada responden sebanyak 233 kuesioner. Namun Kuesioner yang kembali sebanyak 183 kuesioner dan terdapat kuesioner yang rusak atau tidak dapat digunakan sebanyak 6 (enam) kuesioner. Kuesioner yang rusak atau tidak dapat digunakan disebabkan karena ada beberapa pernyataan/ pertanyaan yang tidak ditanggapi oleh responden. Jumlah kuesioner yang tidak kembali sebanyak 50 kuesioner. Kuesioner yang dapat digunakan/diolah sebanyak 177 kuesioner. Secara ringkas data penyebaran dan pengembalian kuesioner disajikan pada Tabel 2.

\section{Karakteristik Responden}

Karakteristik berdasarkan jenis kelamin, jumlah responden pria adalah sebanyak 138 orang atau $77,9 \%$, dan responden wanita sebanyak 39 orang atau 22,03 \%. Karakteristik responden berdasarkan umur menunjukkan bahwa mayoritas responden dalam penelitian ini berusia 36 - 45 tahun sebanyak 84 responden atau 47,46\%. Ini mengindikasikan bahwa responden berada pada rentang usia produktif dalam bekerja. Berdasarkan jenjang pendidikan, sebagian besar responden

Tabel 2. Distribusi dan Pengembalian Kuesioner

\begin{tabular}{lccccc}
\hline \multirow{2}{*}{ Keterangan } & $\begin{array}{c}\text { Kuesioner } \\
\text { yang }\end{array}$ & $\begin{array}{c}\text { Kuesioner } \\
\text { yang tidak }\end{array}$ & \multicolumn{3}{c}{ Kuesioner yang Kembali } \\
\cline { 5 - 6 } disebar & Kembali & $\begin{array}{c}\text { Kuesioner } \\
\text { yang Rusak }\end{array}$ & $\begin{array}{c}\text { Kuesioner yang } \\
\text { digunakan }\end{array}$ \\
\hline Kepala SKPD/Badan & 30 & 8 & 0 & 22 & $73,33 \%$ \\
Kasubbag Keuangan & 30 & 6 & 0 & 24 & $80,005 \%$ \\
Auditor Inspektorat & 23 & 2 & 0 & 21 & $91,30 \%$ \\
DPRD & 50 & 31 & 0 & 19 & $38,00 \%$ \\
Pengusaha & 30 & 1 & 1 & 28 & $93,33 \%$ \\
Aktivis LSM/Yayasan & 35 & 0 & 2 & 33 & $94,29 \%$ \\
Wartawan & 35 & 2 & 3 & 30 & $85,71 \%$ \\
\hline \multicolumn{1}{c}{ Total } & 233 & 50 & 6 & 177 & $\mathbf{7 5 , 9 7 \%}$ \\
\hline \multicolumn{1}{c}{} & & & & &
\end{tabular}


Tabel 3. Karakteristik Responden

\begin{tabular}{llcc}
\hline & Karakteristik Responden & Jumlah & Persentase (\%) \\
\hline Jenis Kelamin & Pria & 138 & 77,97 \\
Umur & Wanita & 39 & 22,03 \\
& 20 - 35 tahun & 30 & 16,95 \\
Pendidikan Terakhir & $35-45$ tahun & 84 & 47,46 \\
& Z46 tahun & 63 & 35,59 \\
& SLTA & 27 & 15,25 \\
& Sarjana (S1) & 117 & 66,10 \\
& Master (S2) & 22 & 12,43 \\
Poktor (S3) & 1 & 0,57 \\
& Lainnya & 10 & 5,65 \\
& Kepala SKPD/Badan & 22 & 12,43 \\
& Kasubbag Keuangan & 24 & 13,56 \\
& Auditor & 21 & 11,86 \\
& Anggota DPRD & 19 & 10,73 \\
& Pengusaha & 28 & 15,82 \\
& Aktivis LSM/Yayasan & 33 & 18,64 \\
& Wartawan & 30 & 16,95 \\
\hline
\end{tabular}

Tabel 4. Karakteristik Variabel

\begin{tabular}{lcccccc}
\hline \multicolumn{1}{c}{ Variabel } & N & Min & Max & Mean & Median & Std. Dev \\
\hline Penyajian Laporan Keuangan (PLK) & 177 & 1.0 & 5.0 & 3.8 & 4.0 & 0.60 \\
Aksesibilitas Laporan Keuangan (ALK) & 177 & 1.0 & 5.0 & 3.3 & 3.3 & 0.90 \\
Transparansi Pengelolaan Keuangan (TP) & 177 & 1.0 & 5.0 & 3.5 & 3,6 & 0.68 \\
Akuntabilitas Pengelolaan Keuangan (AP) & 177 & 1.0 & 5.0 & 3.6 & 3,8 & 0.66 \\
Kepercayaan Stakeholder (KS) & 177 & 1.0 & 5.0 & 3.5 & 3,6 & 0.66 \\
\hline
\end{tabular}

memiliki pendidikan S1 sebanyak 117 responden atau 66,10 \%, yang mengindikasikan bahwa responden memiliki kemampuan yang baik dalam mempelajari dan memahami laporan keuangan. Berdasarkan profesi/jabatan, Sebagian besar responden dalam penelitian ini adalah aktivis LSM/Yayasan yang merupakan public-stakeholder eksternal sebanyak 33 responden atau 18,64\%.

\section{Karakteristik Variabel}

Data-data yang diperoleh melalui kuesioner berupa tanggapan-tanggapan responden terhadap pernyataan-pernyataan positif yang berhubungan dengan indikator masing-masing variabel diukur dengan skala likert. Berikut disajikan statistik deskriptif karakteristik variabel pada Tabel 4 .

Dari Tabel 5 di atas, terdapat 2 indikator yang memiliki nilai loading factor dibawah 0.7 yaitu indikator AP3 pada variabel Akuntabilitas Pengelolaan Keuangan Daerah (AP) dengan nilai loading factor sebesar 0.685, dan indikator KS3 pada variabel Kepercayaan Stakeholder dengan nilai loading factor sebesar 0.603. Hal ini berarti kedua indikator tersebut tidak memenuhi convergent validity, sehingga harus dikeluarkan dari model. Kemudian setelah indikator yang tidak valid dikeluarkan dari model, maka dilakukan analisis PLS Algorithm kembali untuk pengujian tahap II. Hasil evaluasi outer model tahap II menunjukkan bahwa semua indikator memiliki nilai loading factor diatas 0.7 , sehingga dinyatakan memenuhi convergent validity. Selanjutnya, indikator reflektif perlu diuji discriminant validity dimana nilai korelasi cross loading dengan variabel latennya harus lebih besar dibandingkan dengan korelasi terhadap variabel laten yang lain.

Discriminant validity dapat diukur dengan melihat nilai average variance extracted (AVE), akar average variance extracted (AVE) dan nilai korelasi antar konstruk seperti pada Tabel 7. Dari Tabel 7 dapat dilihat semua indikator reflektif masing-masing konstruk sudah valid berdasarkan uji discriminant validity yakni nilai AVE berada di atas 0,5 dan ditunjukkan juga oleh nilai akar AVE dan korelasi konstruk dengan item pengukuran (indikator) lebih besar daripada ukuran konstruk tersebut dengan konstruk lainnya. Setelah uji validitas, dilakukan uji realibilitas data dengan melihat nilai composite reliability dan Cronbach 
Tabel 5. Result For Outer Loading

\begin{tabular}{|c|c|c|c|c|c|}
\hline I / K & ALK & $\overline{\mathbf{A P}}$ & KS & PLK & TP \\
\hline ALK 1 & 0,913 & & & & \\
\hline ALK 2 & 0,865 & & & & \\
\hline ALK 3 & 0,869 & & & & \\
\hline AP 1 & & 0,848 & & & \\
\hline AP 2 & & 0,782 & & & \\
\hline AP 3 & & $0,685^{*}$ & & & \\
\hline $\mathrm{AP} 4$ & & 0,774 & & & \\
\hline AP 5 & & 0,785 & & & \\
\hline KS 1 & & & 0,805 & & \\
\hline KS 2 & & & 0,765 & & \\
\hline KS 3 & & & $0,603^{*}$ & & \\
\hline KS 4 & & & 0,838 & & \\
\hline KS 5 & & & 0,860 & & \\
\hline KS 6 & & & 0,742 & & \\
\hline KS 7 & & & 0,800 & & \\
\hline KS 8 & & & 0,835 & & \\
\hline PLK 1 & & & & 0,844 & \\
\hline PLK 2 & & & & 0,861 & \\
\hline PLK 3 & & & & 0,872 & \\
\hline PLK 4 & & & & 0,873 & \\
\hline TP 1 & & & & & 0,725 \\
\hline ТP 2 & & & & & 0,841 \\
\hline TP 3 & & & & & 0,815 \\
\hline TP 4 & & & & & 0,733 \\
\hline TP 5 & & & & & 0,715 \\
\hline
\end{tabular}

*tidak memenuhi factor loading sehingga dieliminasi

Tabel 6. Result For Cross Loading

\begin{tabular}{cccccc}
\hline I/K & ALK & AP & KS & PLK & TP \\
\hline ALK1 & 0.912 & 0.585 & 0.618 & 0.450 & 0.715 \\
ALK2 & 0.864 & 0.612 & 0.599 & 0.485 & 0.690 \\
ALK3 & 0.871 & 0.634 & 0.596 & 0.483 & 0.698 \\
AP1 & 0.596 & 0.866 & 0.653 & 0.608 & 0.680 \\
AP2 & 0.535 & 0.812 & 0.563 & 0.622 & 0.601 \\
AP4 & 0.471 & 0.790 & 0.596 & 0.669 & 0.589 \\
AP5 & 0.655 & 0.800 & 0.662 & 0.531 & 0.676 \\
KS1 & 0.594 & 0.736 & 0.812 & 0.657 & 0.676 \\
KS2 & 0.496 & 0.617 & 0.776 & 0.504 & 0.547 \\
KS4 & 0.586 & 0.598 & 0.826 & 0.616 & 0.562 \\
KS5 & 0.574 & 0.582 & 0.862 & 0.551 & 0.601 \\
KS6 & 0.548 & 0.520 & 0.745 & 0.502 & 0.575 \\
KS7 & 0.513 & 0.598 & 0.809 & 0.486 & 0.556 \\
KS8 & 0.571 & 0.623 & 0.848 & 0.560 & 0.609 \\
PLK1 & 0.525 & 0.688 & 0.655 & 0.844 & 0.568 \\
PLK2 & 0.400 & 0.577 & 0.526 & 0.861 & 0.518 \\
PLK3 & 0.421 & 0.579 & 0.566 & 0.871 & 0.452 \\
PLK4 & 0.487 & 0.694 & 0.607 & 0.873 & 0.553 \\
TP1 & 0.516 & 0.658 & 0.528 & 0.545 & 0.723 \\
TP2 & 0.788 & 0.610 & 0.645 & 0.454 & 0.841 \\
TP3 & 0.613 & 0.659 & 0.599 & 0.503 & 0.814 \\
TP4 & 0.557 & 0.546 & 0.451 & 0.443 & 0.735 \\
\hline
\end{tabular}


Tabel 7. Nilai AVE, Akar AVE dan Korelasi Antar Konstruk

\begin{tabular}{ccccccc}
\hline I $/$ K & AVE & ALK & AP & KS & PLK & TP \\
\hline ALK & 0,7796 & 0.883 & & & & \\
AP & 0,6691 & 0.692 & 0.818 & & & \\
KS & 0,6593 & 0.685 & 0.758 & 0.812 & & \\
PLK & 0,7430 & 0.536 & 0.742 & 0.686 & 0.862 & \\
TP & 0,5882 & 0.794 & 0.780 & 0.729 & 0.610 & 0.767 \\
\hline
\end{tabular}

Alpha. Nilai composite reliability masing-masing variabel berada di atas 0,7 dan Cronbachs Alpha masing-masing variabel berada di atas 0,6 , sehingga semua variabel dinyatakan realibel.

Tabel 8. Composite Reliability dan Cronbach's Alpha

\begin{tabular}{lcc}
\hline Konstruk & $\begin{array}{c}\text { Composite } \\
\text { Reliability }\end{array}$ & $\begin{array}{c}\text { Cronbachs } \\
\text { Alpha }\end{array}$ \\
\hline ALK & 0.914 & 0.858 \\
AP & 0.890 & 0.834 \\
KS & 0.931 & 0.913 \\
PLK & 0.921 & 0.885 \\
TP & 0.877 & 0.825 \\
\hline
\end{tabular}

\section{Evaluasi Model Struktural (Inner Model)}

Hasil evaluasi inner model disajikan lebih lengkap dalam Tabel 9. Dari tabel 9 di atas dapat dikrtahui nilai t-statistik, nilai signifikansi $p$-value hubungan antar variabel dan nilai koefisien masingmasing variabel. Berikut persamaan inner model yang dihasilkan :

(1) $\mathrm{TP}=0,259 \mathrm{PLK}+0,656 \mathrm{ALK}+\zeta$

(2) $\mathrm{AP}=0,520 \mathrm{PLK}+0,414 \mathrm{ALK}+\zeta$

(3) $\mathrm{KS}=0,352 \mathrm{TP}+0,483 \mathrm{AP}+\zeta$

Keterangan :

PLK = Penyajian laporan keuangan daerah

ALK $=$ Aksesibilitas laporan keuangan Daerah
TP $=$ Transaparansi Pengelolaan Keuangan Daerah AP $=$ Akuntabilitas Pengelolaan Keuangan Daerah $\mathrm{KS}=$ Kepercayaan stakeholders

$\zeta=$ zeta (kecil), galat model struktural

Goodness of fit pada inner model diukur menggunakan koefisien determinasi $\mathbf{R}$ square $\left(\mathbf{R}^{2}\right)$ variabel laten depende (lihat Tabel 10). Pada Tabel 10 dapat disimak bahwa nilai 0,672 untuk konstruk AP yang berarti bahwa aksesibilitas laporan keuangan daerah (ALK) dan penyajian laporan keuangan daerah (PLK) mampu menjelaskan varians akuntabilitas pengelolaan keuangan daerah (AP) sebesar $67.2 \%$ dan sisanya sebesar $32.8 \%$ dijelaskan oleh variabel-variabel lain di luar variabel PLK dan ALK. Nilai R-Square juga terdapat pada KS dan TP. Konstruk TP mendapatkan nilai 0,623 yang berarti bahwa aksesibilitas laporan keuangan daerah (ALK) dan penyajian laporan keuangan daerah (PLK) mampu menjelaskan varians transparansi pengelolaan keuangan daerah (TP) sebesar $62.3 \%$ dan sisanya sebesar $37.7 \%$ dijelaskan oleh variabel-variabel lain di luar variabel PLK dan ALK. Selanjutnya KS mendapatkan nilai 0,679 yang berarti bahwa transparansi pengelolaan keuangan daerah (TP) dan akuntabilitas pengelolaan keuangan daerah (AP) mampu menjelaskan varians kepercayaan publicstakeholders (KS) sebesar 67,9 \% dan sisanya sebesar 32,1\% dijelaskan oleh konstruk lain di luar penelitian ini.

Tabel 9. Path Coeficients (Mean, STDEV, T-Value)

\begin{tabular}{cccccc}
\hline $\begin{array}{c}\text { Hubungan Antar } \\
\text { Variabel }\end{array}$ & $\begin{array}{c}\text { Original } \\
\text { Sample (O) }\end{array}$ & $\begin{array}{c}\text { Standard Error } \\
(\text { STERR) }\end{array}$ & $\begin{array}{c}\text { T Statistics } \\
(\mid \text { O/STERR } \mid)\end{array}$ & $\begin{array}{c}\text { P- } \\
\text { Values }\end{array}$ & Kesimpulan \\
\hline PLK -> TP & 0.259 & 0.057 & 4.514 & 0.000 & H1a diterima \\
PLK -> AP & 0.520 & 0.052 & 9.982 & 0.000 & H1b diterima \\
ALK -> TP & 0.656 & 0.049 & 13.459 & 0.000 & H2a diterima \\
ALK -> AP & 0.414 & 0.050 & 8.244 & 0.000 & H2b diterima \\
TP > KS & 0.352 & 0.080 & 4.405 & 0.000 & H3 diterima \\
AP -> KS & 0.483 & 0.096 & 5.009 & 0.000 & H4 diterima \\
\hline
\end{tabular}


Tabel 10. R-Square

\begin{tabular}{lc}
\hline Konstruk & $\boldsymbol{R}$-Square $\left(\mathrm{R}^{2}\right)$ \\
\hline ALK & - \\
AP & 0,672 \\
KS & 0,623 \\
PLK & - \\
TP & 0,679 \\
\hline
\end{tabular}

\section{Pengaruh Penyajian Laporan Keuangan Daerah Terhadap Transparansi Pengelolaan Keuangan Daerah}

Diamod (2002) menyatakan bahwa informasi keuangan di dalam laporan keuangan dapat memberikan manfaat atas meningkatnya transparansi dari aktivitas pemerintah. Hal yang sama juga diungkapkan Nordiawan, (2010) bahwa penyajian informasi yang utuh dalam laporan keuangan akan menciptakan transparansi dan nantinya akan menciptakan akuntabilitas. Hasil penelitian ini menunjukkan bahwa penyajian laporan keuangan daerah (PLK) berpengaruh signifikan dan positif terhadap transparansi pengelolaan keuangan daerah (TP). Uji hipotesis menunjukkan t-statistik sebesar 4,514 lebih besar dari t-tabel sebesar 1,68 dan dengan nilai signifikansi p-value sama dengan 0.000 , lebih kecil dari 0,05 , maka hipotesis la yang menyatakan penyajian laporan keuangan daerah (PLK) berpengaruh signifikan dan positif terhadap transparansi pengelolaan keuangan daerah (TP) terbukti dan dapat diterima. Hasil penelitian ini sejalan dengan hasil penelitian Mulyana (2006), Nasution (2009), Bandariy (2011), serta Aliyah dan Nahar (2012) yang menyatakan bahwa penyajian laporan keuangan daerah dan aksesibilitas laporan keuangan daerah secara parsial maupun bersamasama berpengaruh positif dan signifikan terhadap transparansi dan akuntabilitas pengelolaan keuangan daerah. Ini artinya, semakin baik penyajian laporan keuangan akan berpengaruh terhadap meningkatnya transparansi pengelolaan keuangan daerah.

\section{Pengaruh Aksesibilitas Laporan Keuangan Daerah Terhadap Transparansi Pengelolaan Keuangan Daerah}

Aksesibilitas laporan keuangan merupakan kemudahan bagi seseorang untuk memperoleh informasi mengenai laporan keuangan (Mulyana, 2006). Menurut Mardiasmo (2002), laporan keuangan pemerintah merupakan hak publik yang harus diberikan oleh pemerintah, baik pusat maupun daerah. Masyarakat sebagai pihak yang memberi kepercayaan kepada pemerintah untuk mengelola keuangan publik berhak untuk mendapatkan informasi keuangan pemerintah untuk melakukan evaluasi terhadap pemerintah. Hasil penelitian ini menunjukkan bahwa aksesibilitas berpengaruh terhadap transparansi pengelolaan keuangan daerah. Hasil uji hipotesis menunjukkan nilai t-statistik sebesar 9.982 lebih besar dari t-tabel sebesar 1,68 dan dengan nilai signifikansi $P$-Value sebesar 0.000 , kurang dari alpha $5 \%$ (0.05), maka hipotesis $1 \mathrm{~b}$ yang menyatakan aksesibilitas laporan keuangan daerah (ALK) berpengaruh secara positip dan signifikan terhadap transparansi pengelolaan keuangan daerah diterima.

Hasil penelitian ini sejalan dengan penelitian Mulyana (2006), Nasution (2009), Pasaribu (2009), Bandariy (2011), Aliyah dan Nahar (2012), dan Wahyuni (2014) yang telah melakukan penelitian untuk menguji secara empiris pengaruh penyajian laporan keuangan dan aksesibilitas laporan keuangan terhadap transparansi dan akuntabilitas pengelolaan keuangan daerah. Hasil penelitian mereka menunjukkan bahwa aksesibilitas laporan keuangan daerah secara parsial berpengaruh positif dan signifikan terhadap transparansi pengelolaan keuangan daerah.

Analisis statistik deskripsi menyatakan bahwa rata-rata tanggapan responden atas aksesibilitas laporan keuangan pemerintah daerah Kabupaten Lombok Timur adalah tersedia, terbuka dan mudah diakses. Begitu juga mengenai transparansi pengelolaan keuangan daerah, rata-rata responden mengatakan cukup transparan. Ini menunjukkan bahwa statistik deskriptif penelitian ini sesuai dengan hasil uji hipotesis $1 \mathrm{~b}$ yang menyatakan bahwa aksesibilitas laporan keuangan daerah berpengaruh positif dan signifikan terhadap transparansi pengelolaan keuangan daerah.

\section{Pengaruh Penyajian Laporan Keuangan Daerah Terhadap Akuntabilitas Pengelolaan Keuangan Daerah}

Penyajian informasi yang utuh dalam laporan keuangan akan menciptakan transparansi dan nantinya menciptakan akuntabilitas (Nordiawan, 2010). Salah satu manfaat Informasi keuangan di dalam laporan keuangan daerah menurut Diamond (2002) adalah meningkatkan akuntabilitas untuk para manajer (kepala daerah dan para pejabat pemda). Mereka bertanggung jawab tidak hanya pada kas masuk dan kas keluar, tetapi juga 
pada aset dan utang yang mereka kelola. Hasil penelitian ini menunjukkan t-statistik sebesar 13,459 lebih besar dari t-tabel sebesar 1,68 dan dengan nilai signifikansi $P$-Value sebesar 0.000, lebih kecil dari alpha sebesar 0,5\%(0,05), maka hipotesis 2a yang menyatakan bahwa penyajian laporan keuangan daerah (PLK) berpengaruh positif dan signifikan terhadap akuntabilitas pengelolaan keuangan daerah (AP) diterima. Ini artinya, semakin baik informasi keuangan yang disajikan dalam laporan keuangan maka semakin meningkat akuntabilitas pengelolaan keuangan daerah (AP) yang dilakukan oleh pemerintah.

Hasil penelitian ini sejalan dengan penelitian Mulyana (2006), Nasution (2009), Bandariy (2011), Aliyah dan Nahar (2012), dan Wahyuni (2014) yang menyatakan bahwa secara parsial dan simultan penyajian laporan keuangan berpengaruh signifikan dan positif terhadap transparansi dan akuntabilitas pengelolaan keuangan daerah. Penelitian ini juga sejalan dengan penelitian Sukhemi (2010), Mustafa (2012), Sande (2012) dan Wahyuni (2013) yang menyatakan, penyajian laporan keuangan (PLK) berpengaruh positif dan signifikan terhadap akuntabilitas pengelolaan keuangan daerah (AP)

Dari hasil analisis statistik deskriptif, rata-rata responden memberi tanggapan atas penyajian laporan keuangan daerah Kabupaten Lombok Timur adalah jujur, relevan, dapat dibandingkan dan dapat dipahami. Responden juga memberi tanggapan atas akuntabilitas pengelolaan keuangan yang menyatakan bahwa pengelolaan keuangan daerah akuntabel. Semakin baik penyajian laporan keuangan maka semakin meningkat akuntabilitas pengelolaan keuangan daerah (AP). Akuntabilitas keuangan pemerintah daerah Kabupaten Lombok Timur dilakukan dalam bentuk pengungkapan, dan ketaatan terhadap peraturan perundanganundangan. Selain itu hal ini juga didukung dengan memublikasikan laporan keuangan melalui media, seperti: surat kabar, majalah, radio, stasiun televisi, dan website, serta forum yang memberikan perhatian langsung atau peranan yang mendorong akuntabilitas pemerintah.

\section{Pengaruh Aksesibilitas Laporan Keuangan Daerah Terhadap Akuntabilitas Pengelolaan Keuangan Daerah}

Untuk menciptakan akuntabilitas pengelolaan keuangan daerah, pemda harus menyampaikan laporan pertanggungjawaban berupa laporan keuangan kepada masyarakat dengan mengembangkan
Sistem Informasi Keuangan Daerah (SIKD) sebagai salah satu prasyarat untuk memenuhi prinsip transparansi dan akuntabilitas pegelolaan keuangan daerah. Di dalam demokrasi yang terbuka, akses ini diberikan oleh media, seperti surat kabar, majalah, radio, stasiun televisi, dan website dan forum yang memberikan perhatian langsung atau peranan yang mendorong akuntabilitas pemerintah terhadap masyarakat (Shende dan Bennet, 2004). Semakin mudah masyarakat mengakses laporan keuangan daerah maka akuntabilitas pengelolaan keuangan daerah semakin meningkat. Hasil uji hipotesis menunjukkan t-statistik sebesar 8,244 lebih besar dari t-tabel sebesar 1,671 dan dengan nilai signifikansi $p$-value sebesar 0.000 , lebih kecil dari 0,05, maka hipotesis $2 \mathrm{~b}$ yang menyatakan bahwa Aksesibilitas laporan keuangan daerah (ALK) berpengaruh positif dan signifikan terhadap akuntabilitas pengelolaan keuangan daerah (AP) dapat dibuktikan dan diterima.

Hasil penelitian ini sejalan dengan penelitian Mulyana (2006) tentang pengaruh penyajian neraca daerah dan aksesibilitas laporan keuangan terhadap transparansi dan akuntabilitas pengelolaan keuangan daerah. Hasil penelitiannya menunjukkan bahwa penyajian neraca daerah dan aksesibilitas laporan keuangan secara parsial dan simultan berpengaruh signifikan terhadap transparansi dan akuntabilitas pengelolaan keuangan daerah. Aliyah dan Nahar (2012), Mustafa (2012), Wahyuni (2014) yang meneliti tentang pengaruh penyajian laporan keuangan dan aksesibilitas laporan keuangan terhadap transparansi dan akuntabilitas pengelolaan keuangan daerah. Hasil penelitiannya menunjukkan bahwa penyajian laporan keuangan dan aksesibilitas laporan keuangan secara parsial dan simultan berpengaruh signifikan terhadap transparansi dan akuntabilitas pengelolaan keuangan daerah. Hasil penelitian ini juga mendukung hasil penelitian yang dilakukan oleh Sande (2013) dan Riyansa et al. (2015) yang meneliti tentang pengaruh aksesibilitas laporan keuangan daerah terhadap akuntabilitas pengelolaan keuangan daerah.

Dari analisis statistik deskriptif, dapat diketahui bahwa rata-rata tanggapan responden atas aksesibilitas laporan keuangan pemerintah daerah Kabupaten Lombok Timur adalah tersedia, terbuka dan mudah diakses. Begitu juga mengenai akuntabilitas pengelolaan keuangan daerah, ratarata responden mengatakan akuntabel. Ini menunjukkan bahwa statistik deskriptif penelitian ini mendukung hasil uji hipotesis H2a yang menyatakan bahwa aksesibilitas laporan keuangan daerah 
berpengaruh positif dan signifikan terhadap transparansi pengelolaan keuangan daerah. Ini berarti semakin meningkat aksesibilitas laporan keuangan daerah semakin meningkat akuntabilitas pengelolaan keuangan daerah.

\section{Pengaruh Transparansi Pengelolaan Keuangan Daerah Terhadap Kepercayaan Public- Stakeholder}

Mardiasmo (2005) menjelaskan bahwa transparansi berarti keterbukaan (openness) pemerintah dalam memberikan informasi yang terkait dengan aktivitas pengelolaan sumber daya publik kepada pihak-pihak yang membutuhkan informasi (lihat juga: Ulum dan Sofyani, 2016). Salah satu prinsip kepemerintahan yang baik menurut Peraturan Pemerintah No. 101 tahun 2000 adalah transparansi menciptakan kepercayaan timbal-balik antara pemerintah dan masyarakat melalui penyediaan informasi dan menjamin kemudahan di dalam memperoleh informasi yang akurat dan memadai. Hasil uji hipotesis penelitian ini adalah t-statistik sebesar 4,405 lebih besar dari t-tabel sebesar 1,68 dan dengan nilai signifikansi $p$-value sebesar 0.000 , lebih kecil dari 0,05, maka hipotesis 3 yang menyatakan transparansi pengelolaan keuangan daerah berpengaruh terhadap kepercayaan publicstakeholder diterima.

Penelitian ini mendukung hasil penelitian Rahmawati (2013) yang meneliti pengaruh transparansi dan akuntabilitas pemerintah daerah terhadap kepuasan dan kepercayaan masyarakat di Daerah Istimewa Yogyakarta. Penelitian ini juga mendukung hasil penelitian Tolbert dan Mossberger (2006) dan hasil penelitian Welch, et.al (2004). Penelitian Tolbert dan Mossberger (2006) menguji perilaku masyarakat terhadap pelaksanaan e-government dan pengaruhnya terhadap kepercayaan masyarakat kepada pemerintah. Hasil penelitiannya menunjukkan bahwa pelaksanaan e-government meningkatkan persepsi masyarakat terhadap transparansi pemerintah. Dan hasil penelitian Welch, et.al (2004) menemukan bahwa penggunaan e-government dan website pada masyarakat berhubungan positif dengan kepuasan masyarakat kepada pemerintah.

Analisis statistik deskriptif menjelaskan bahwa rata-rata tanggapan responden atas transparansi pengelolaan keuangan daerah pemerintah kabupaten lombok timur adalah transparan. Responden juga memberi tanggapan atas kepercayaan publicstakeholder kepada pemda Kabupaten Lombok Timur adalah baik. Hal ini menunjukkan bahwa statistik deskriptif penelitian ini mendukung hasil uji hipotesis 3 yang menya-takan bahwa transparansi pengelolaan keuangan daerah berpengaruh positif dan signifikan terhadap kepercayaan public-stakeholder. Dari hasil ini maka dapat disimpulkan semakin transparan pengelolaan laporan keuangan pemerintah daerah, maka public-stakeholder lapo-ran keuangan daerah akan memberi kepercayaan yang semakin tinggi kepada pemda.

\section{Pengaruh Akuntabilitas Pengelolaan Keuangan Daerah Terhadap Kepercayaan Public- Stakeholder}

Akuntabilitas publik bertujuan untuk mendorong terciptanya kinerja yang baik dan terpercaya. Semakin tinggi tingkat akuntabilitas pengelolaan keuangan daerah maka semakin tinggi kepercayaan public-stakeholders terhadap pemerintah daerah (Mardiasmo, 2002). Untuk menjaga kepercayaan stakeholder, pemerintah daerah sebagai steward akan bertindak secara kolektif dan bersama-sama dengan jajarannya mempertanggungjawabkan pengeloalaan keuangan daerah dan sumber daya lainnya (Mardiasmo, 2002). Hasil uji hipotesis penelitian ini menunjukkan t-statistik sebesar 5,009 lebih besar dari t-tabel sebesar 1,671 dan dengan nilai signifikansi $P$-Value sebesar 0.000, lebih kecil dari $0,5 \%(0,05)$. Dengan demikian maka hipotesis 4 yang menyatakan akuntabilitas pengelolaan keuangan daerah berpengaruh positif dan signifikan terhadap kepercayaan stakeholder dapat diterima.

Penelitian ini sejalan dengan hasil penelitian Rahmawati (2013) yang meneliti pengaruh transparansi dan akuntabilitas pemerintah daerah terhadap kepuasan dan kepercayaan masyarakat di Daerah Istimewa Yogyakarta. Hasil penelitian menunjukkan bahwa terdapat pengaruh akuntabilitas pemerintah daerah terhadap kepuasan dan kepercayaan masyarakat kepada pemda. Hasil penelitian ini juga mendukung penelitian yang dilakukan oleh Fard dan Rostamy (2007) yang meneliti pengaruh akuntabilitas terhadap kepuasan dan kepercayaan masyarakat. Hasil penelitiannya mengindikasikan bahwa akuntabilitas pemerintah mempengaruhi kepercayaan masyarakat kepada pemerintah dengan peningkatan kepuasaan masyarakat atas kinerja pemda.

Analisis statistik deskriptif menjelaskan bahwa rata-rata tanggapan responden atas akuntabilitas pengelolaan keuangan daerah pemerintah KabuPaten Lombok Timur adalah akuntabel. Tangga- 
pan responden atas kepercayaan publicstakeholder terhadap pemda Kabupaten Lombok Timur menunjukkan bahwa sebagian besar responden menyatakan percaya terhadap pemda. Hal ini menunjukkan bahwa hasil statistik deskriptif mengenai akuntabilitas pengelolaan keuangan daerah dan kepercayaan public-stakeholder sesuai dengan hipotesis 4 yang menyatakan bahwa aksesibilitas laporan keuangan daerah berpengaruh positif dan signifikan terhadap transparansi pengelolaan keuangan daerah. Semakin akuntabel pengelolaan keuangan daerah, maka semakin meningkat kepercayaan public-stakeholder terhadap pemda.

\section{SIMPULAN ${ }^{2}$}

Penelitian ini bertujuan untuk menguji dan memberikan bukti empiris pengaruh penyajian dan aksesibilitas laporan keuangan daerah terhadap transparansi dan akuntabilitas pengelolaan keuangan daerah dan dilanjutkan dengan menguji pengaruh transparansi dan akuntabilitas pengelolaan keuangan daerah terhadap kepercayaan public-stakeholders. Pengujian dilakukan dengan menggunakan analisis Partial Least Square (PLS).

Hasil penelitian ini memberikan bukti bahwa penyajian laporan keuangan daerah berpengaruh positif dan signifikan terhadap transparansi pengelolaan keuangan daerah. Semakin berkualitas Penyajian laporan keuangan daerah maka transparansi pengelolaan keuangan Pemerintah Daerah Kabupaten Lombok Timur semakin meningkat. Penyajian laporan keuangan yang berkualitas adalah penyajian laporan keuangan yang jujur, relevan, dapat dibandingkan dan dapat dipahami. Hasil penelitian ini juga memberikan bukti bahwa terdapat pengaruh positif dan signifikan aksesibilitas laporan keuangan daerah terhadap transparansi pengelolaan keuangan daerah. Hal ini menunjukkan bahwa laporan keuangan daerah yang terbuka, tersedia dan accesable akan meningkatkan transparansi pengelolaan keuangan daerah. Pemda Kabupaten Lombok Timur dapat memanfaatkan website pemerintah daerah untuk memublikasikan laporan keuangan daerah sebagai wujud transparansi pengelolaan keuangan daerah.

\footnotetext{
2 Penggunaan istilah stakeholder dan public-stakeholder pada artikel ini digunakan silih berganti dengan maksud yang disamakan.
}

Penelitian ini memberikan bukti bahwa penyajian laporan keuangan daerah berpengaruh positif dan signifikan terhadap akuntabilitas pengelolaan keuangan daerah. Semakin baik penyajian laporan keuangan Pemda Kabupaten Lombok Timur akan semakin akuntabel pelaporan keuangan pemerintah daerah tersebut. Penyajian laporan keuangan yang jujur, relevan, dapat dibandingkan dan dipahami merupakan wujud dari akuntabilitas pengelolaan keuangan daerah. Selain penyajian laporan keuangan yang baik, keterbukaan atau aksesibilitas laporan keuangan juga sangat penting dalam sebuah pertanggungjawaban.

Penelitian ini memberikan bukti bahwa aksesibilitas laporan keuangan daerah berpengaruh positif dan signifikan terhadap akuntabilitas pengelolaan keuangan daerah. Hal ini menunjukkan bahwa laporan keuangan yang terbuka, tersedia dan mudah diperoleh oleh masyarakat akan meningkatkan akuntabilitas pengelolaan keuangan daerah. Pemerintah daerah Kabupaten Lombok Timur telah berusaha memberikan kemudahan dan menyediakan data-data yang berhubungan dengan pelaksanaan program dan sebagian aktivitas keuangan pemerintah melalui website pemda. Penelitian ini memberikan bukti bahwa terdapat pengaruh positif dan signifikan transparansi pengelolaan keuangan daerah terhadap kepercayaan public-stakeholders. Hal ini menunjukkan bahwa keterbukaan dalam laporan keuangan akan melahirkan kepercayaan para pemangku kepentingan kepada pemerintah daerah. Oleh karena itu, peran website pemerintah daerah Kabupaten Lombok Timur perlu ditingkatkan kapasitasnya agar publicstakeholder dapat dengan mudah mengakses laporan keuangan daerah.

Penelitian ini juga memberikan bukti bahwa terdapat pengaruh positif dan signifikan akuntabilitas pengelolaan keuangan daerah terhadap kepercayaan public-stakeholders. Artinya, pengelolaan keuangan daerah yang akuntabel akan meningkatkan kepercayaan stakeholder kepada pemerintah daerah. Hal ini menunjukkan bahwa pemerintah daerah Kabupaten Lombok Timur perlu meningkatkan akuntabilitas pengelolaan keuangan daerahnya agar kepercayaan publicstakeholders kepada pemda semakin meningkat.

Keterbatasan penelitian ini dapat menjadi bahan evaluasi dan masukan bagi peneliti selanjutnya. Keterbatasan yang dihadapi dalam penelitian ini antara lain adalah penelitian ini hanya menggunakan stakeholder laporan keuangan pada Pemda Kabupaten Lombok Timur, sehingga generalisasi hasil penelitian ini tidak dapat diberlakukan 
bagi public-stakeholder laporan keuangan di daerah lain. Penelitian ini juga tidak mengeksplorasi faktor-faktor lain seperti pengungkapan laporan keuangan, pengendalian intern, karakteristik budaya daerah, dan kompetensi sumber daya manusia.

Penelitian ini menggunakan sampel penelitian masih tergolong kecil mengingat waktu penelitian yang terbatas dan masih ada variabel yang memiliki validitas rendah yaitu variabel transparansi pengelolaan keuangan daerah karena kurang dominan dalam memprediksi blognya sendiri terhadap korelasi antar konstruk laten/variabel lainnya. Hal ini menandakan bahwa pernyataan atas indikator dalam kuesioner perlu dilakukan evaluasi. Selain itu, penelitian ini memakai satu pernyataan atau pertanyaan dalam satu indikator yang dikenal dengan first order confirmatory.

Penelitian mendatang perlu mengembangkan obyek penelitian yang lebih luas yang melingkupi wilayah propinsi atau negara dengan jumlah sampel yang lebih besar dan waktu yang memadai. Peneliti juga menyarankan arah penelitian selanjutnya agar mempertimbangkan penggunaan sampel dari stakeholder eksternal saja, atau publicstakeholder internal saja atau memperbandingkan keduanya. Pada penelitian selanjutnya juga perlu menggali indikator-indikator dan faktor-faktor lain yang berhubungan dengan transparansi dan akuntabilitas pengelolaan keuangan daerah.

Di dalam pengumpulan data, instrumen penelitian (kuesioner) perlu dilakukan evaluasi, khususnya yang berhubungan dengan pernyataan mengenai indikator-indikator variabel transparansi pengelolaan keuangan daerah agar lebih mudah dipahami, tidak bias atau tidak mengarahkan jawaban responden. Selain itu, penelitian selanjutnya dapat menggunakan analisis second order confirmatory dengan alat analisis SEM-PLS (CBSEM) mengingat masing-masing variabel memiliki dimensi dan dimensi memiliki banyak indikator.

\section{DAFTAR PUSTAKA}

Bandariy, H. 2011. Pengaruh Penyajian Laporan Keuangan Daerah dan Aksesibilitas Laporan Keuangan terhadap Penggunaan Informasi Keuangan Daerah. Tesis, Universitas Diponegoro.

Badan Pemeriksa Keuangan Republik Indonesia. 2014. Laporan Hasil Pemeriksaan BPK RI atas Laporan Keuangan Pemerintah Daerah
Kabupaten Lombok Timur Tahun Anggaran 2013, Perwakilan Provinsi NTB.

Diamond, J. 2002. Performance Budgeting Is Accrual Accounting equired. IMFWorking Paper. Fiscal Affairs Department.

Eisenhardt, K.M. 1989. Building Theories From Case Study Research. Academy of Management Review, 14 (4), 532-550.

Fard, H. D. dan A. A. Rostamy. 2007. Promoting Public Trust in Public Organization: Explaining the Role of Public Accountability. Public Organization Review, 7, 331-344.

Ghozali, I. 2008. Aplikasi Analisis Multivariate dengan Program SPSS. Semarang: Badan Penerbit Undip Semarang.

Grosso, A. L., dan G. V. Gregg. 2011. How Citizens View Governmen Performance Reporting. Public Performance \& Management Review, 35, 235-250.

Gunawan, B. 2000. Pengumuman Hasil Audit Badan Pemeriksa Keuangan terhadap Bank Indonesia sebagai Upaya untuk Melakukan Transparansi dan Akuntabilitas Bank Indonesia (Suatu Tinjauan dari Sisi Audit). Jurnal Akuntansi dan Investasi, 1 (2), 93103.

Hartono, J., dan Abdillah. 2009. Konsep dan Aplikasi PLS (Partial Least Square) untuk Penelitian Empiris. Yogyakarta: BPFE Yogyakarta.

Hartono, J. 2011. Konsep Dan Aplikasi Structural Equation Modeling Berbasis Varian Dalam Penelitian Bisnis. Yogyakarta: UPP STIM YKPN.

Republik Indonesia. Intruksi Presiden (Inpres) nomor 7 tahun 1999 tentang Laporan Akuntabilitas Kinerja Instansi Pemerintah.

Jones, D. B. 1985. The Needs of Users of Governmental Financial Reports. Government Accounting Standards Board.

Judith, H., M. Karen dan R. Randall. 2009. Building Trust or Mistrust: The Search for Performance Reporting from a Citizen's Perspective. The Journal of Government Financial Management, Winter, 40-46.

Kabupaten Lombok Timur, Peraturan Daerah Nomor 7 Tahun 2009 tentang Pokok-Pokok Pengelolaan Keuangan Daerah $D_{I}$ Kabupaten Lombok Timur

Krisnayanti ,I. A. P. A. 2013. Analisis Persepsi Stakeholder Internal Dan Eksternal Terhadap Transparansi Dan Akuntabilitas Laporan Keuangan Pengelolaan Dana BOS 
di SMP Negeri 1 Banjar. Skripsi, Universitas Pendidikan Ganesha.

LAN dan BPKP. 2003. Pedoman Penyusunan Pelaporan Akuntabilitas Kinerja Instansi Pemerintah, Jakarta. Penerbit LAN RI

Mardiasmo. 2002. Akuntansi Sektor Publik. Yogyakarta: Penerbit Andi.

, 2005. Perwujudan Transparansi dan Akuntabilitas Publik Melalui Akuntansi Sektor Publik: Suatu Sarana Good Governance. Jurnal Akuntansi Pemerintah, 2 (1), 1-17.

Mudhofar, K. dan A. Tahar. 2016. Pengaruh Desentralisasi Fiskal dan Kinerja Terhadap Akuntabilitas Pelaporan Keuangan Pemerintah Daerah di Indonesia: Efek Moderasi dari Kinerja. Jurnal Akuntansi dan Investasi, 17 (2), 176-185.

Mulyana, B. 2006. Pengaruh Penyajian Neraca Daerah dan Aksesibilitas Laporan Keuangan terhadap Transparansi dan Akuntabilitas Pengelolaan Keuangan Daerah. Jurnal Akuntansi Pemerintah, 2.

Murtin, A. 2008. Persepsi Masyarakat Terhadap Kualitas Layanan Publik yang Diberikan Oleh Instansi Pemerintah di Kabupaten Sleman Dan Kabupaten Bantul. Jurnal Akuntansi dan Investasi, 9 (1), 80-90.

Mustafa, A. I. 2012. Pengaruh Penyajian dan Aksesibilitas Laporan Kuangan terhadap Akuntabilitas Pengelolaan Keuangan Kabupaten Pemalang. Journal unnes. ac.id

Nahar, A. dan S. Aliyah. 2012. Pengaruh penyajian laporan keuangan SKPD dan aksesibilitas laporan keuangan SKPD terhadap transparansi dan akuntabilitas pengelolaan keuangan Daerah Kabupaten Jepara. Skripsi, Sekolah Tinggi Ilmu Ekonomi Nahdlatul Ulama Jepara.

Nasution. S. I. 2009. Pengaruh penyajian neraca SKPD dan aksesibilitas laporan keuangan SKPD terhadap transparansi dan akuntabilitas pengelolaan keuangan SKPD di Pemerintahan Provinsi Sumatera Utara. Skripsi, Universitas Sumatera Utara.

Nordiawan, D. 2010. Akuntansi Sektor Publik. Jakarta: Salemba Empat.

Nugraha, M. Q. 2007. Manajemen Strategik Organisasi Publik, Penerbit Universitas Terbuka, Edisi I.

Pasaribu, F. J. 2011. Pengaruh penyajian laporan keuangan SKPD dan aksesibilitas laporan keuangan SKPD terhadap Transparansi dan Akuntabilitas Pengelolaan Keuangan SKPD. Tesis, Universitas Sumatera Utara.

Pratolo, S. 2016. Transparansi Dan Akuntabilitas Tata Kelola Pemerintahan Daerah dalam Hubungannya dengan Perwujudan Keadilan Dan Kinerja Pemerintah Daerah: Sudut Pandang Aparatur dan Masyarakat Di Era Otonomi Daerah. Jurnal Akuntansi dan Investasi, 9 (2), 108-124.

Puspita, R. dan D. Martani. 2010. Analisis Pengaruh Kinerja Dan Karakteristik Pemda Terhadap Tingkat Pengungkapan Dan Kualitas Informasi Dalam Website Pemda. Skripsi, Universitas Indonesia.

Raharjo, E. 2007. Teori Agensi dan Teori Stewardship dalam Perspektif Akuntansi. Dalam Fokus Ekonomi, 2 (1).

Rahmawati, N. E. 2013. Pengaruh Transparansi dan Akuntabilitas Pemerintah Daerah terhadap Kepuasaan dan Kepercayaan Stakeholder. Tesis, Universitas Gadjah Mada.

Ramadhani. 2011. Persepsi Stakeholder Internal terhadap Akuntabilitas dan Transparansi Laporan Keuangan Universitas Sebelas Maret Pasca ditetapkan sebagai Badan Layanan Umum. Skripsi, Universitas Sebelas Maret.

Republik Indonesia, Undang-undang Nomor 28 Tahun 1999 tentang Penyelenggaraan Negara yang Bebas dari Korupsi, Kolusi, dan nepotisme.

, Undang-undang

Nomor 17 Tahun 2003 tentang Keuangan Negara.

32 Tahun 2004 tentang Pemerintahan

Peraturan Menteri Dalam Negeri Nomor 59 Tahun 2007 tentang Perubahan atas Peraturan Menteri Dalam Negeri Nomor 13 Tahun 2006 tentang Pedoman Pengelolaan Keuangan Daerah

Peraturan Pemerintah Nomor 24 Tahun 2005 tentang Standar Akuntansi pemerintah. Peraturan Pemerintah Nomor 58 Tahun 2005 tentang Pengelolaan Keuangan Daerah

Peraturan Pemerintah Nomor 101 Tahun 2000 tentang Pendidikan dan Pelatihan negeri Sipil

Ridha, A. M., dan H. Basuki. 2012. Pengaruh Tekanan Eksternal, Ketidakpastian Lingkungan, dan Komitmen Managemen 
terhadap Penerapan Transparansi Laporan Keuangan.

Riyansa, R., Yunilma dan P. Fauziati. 2015, Pengaruh Penyajian Laporan Keuangan dan Aksesibilitas Laporan Keuangan terhadap Akuntabilitas Pengelolaan Keuangan Daerah (Studi Empiris Pada Pemerintah Kabupaten Padang Pariaman), Skripsi, Universitas Bung Hatta.

Safitri, R. A. 2009. Pengaruh Penyajian Laporan Keuangan Daerah Dan Aksesibilitas Laporan Keuangan Terhadap Penggunaan Informasi Keuangan Daerah (Studi Empiris Di Kabupaten Semarang), Skripsi, Universitas Diponegoro.

Shende, S. dan T. Bennet. 2004. Concept Paper 2: Transparency and Accountability in Public Financial Administration. UN DESA.

Sofyani, H., dan R. Akbar. 2013. Hubungan Faktor Internal Institusi dan Implementasi Sistem Akuntabilitas Kinerja Instansi Pemerintah (SAKIP) di Pemerintah Daerah. Jurnal Akuntansi dan Keuangan Indonesia, 10 (2), 184-205.

Sofyani, H. dan R. Akbar. 2015. Hubungan Karakteristik Pegawai Pemerintah Daerah dan Implementasi Sistem Pengukuran Kinerja: Perspektif Ismorfisma Institusional. Jurnal Akuntansi \& Auditing Indonesia, 19 (2), 153-173.

Steccolini, I. 2002. Local Government Annual Report: an Accountability Medium? Paper Dipresentasikan Pada EIASM Conference on Accounting and Auditing in Public Sector Performs, Durbin.

Sugiyono. 2010. Metode Penelitian Kuantitatif, Kualitatif dan R \& D. Bandung: Alfabeta.

Sugiyono. 2013. Metode Penelitian Bisnis. Bandung: Alfabeta

Sukhemi. 2010. Pengaruh Penyajian Neraca Daerah Terhadap Akuntabilitas Keuangan Daerah, Akmenika Jurnal Akuntansi dan Manajemen, 5, 85-100.

Tschannen-Moran, M. and Hoy, A.W. (2001). Teacher efficacy: Capturing an elusive construct. Teaching and Teacher Education Journal, 17,783-805.

Tolbert, C. J., dan K. Mossberger. 2006. The Effects of E-Government on Trust and Confidence in Government. Public Administration Review, 354-369.

Ulum, I. dan H. Sofyani. 2016. Akuntansi (Sektor) Publik. Yogyakarta: Aditya Publishing.
Wahyuni, P. S., Sulindawati, N. L. G. Erni, dan H. N. Trisna. 2014. Pengaruh penyajian laporan keuangan daerah dan aksesibilitas laporan keuangan daerah terhadap akuntabilitas pengelolaan keuangan daerah (studi empiris pada pemerintahan Kabupaten Badung). e-Journal Akuntansi Universitas Pendidikan Ganesha, 2 (1).

Welch, E. W., C. H. Charles dan M. J. Moon. 2004. Linking Citizen Satisfaction with EGovernment and Trust in Government. Journal of Public Administration Research and Theory, 15, 371-391. 